\title{
Implementation of Zero Etanol in the Analysis of Lambucid Tablet Sampling at PT. Kalbe Farma Tbk
}

\author{
Nisa Nurhidayanti ${ }^{*}$, Deni Rusli ${ }^{1}$ \\ ${ }^{1,2}$ Department of Environmental Engineering, Faculty of Engineering, Pelita Bangsa University, \\ Inspection Kalimalang Tegal Danas Direction Delta Mas street, Cikarang Center, Bekasi Regency, 17530 \\ *Corresponding Author, email: nisa.kimia@pelitabangsa.ac.id \\ (c) (1) (0)
}

\begin{abstract}
PT. Kalbe Farma Tbk Bekasi is one of the pharmaceutical industries in Indonesia which has an essential role in the world of health because it produces several different preparations of drugs, one of which is lambucid tablets as medicine for heartburn. The ethanol waste produced in the production of lambucid tablets is toxic and can pollute the environment if it is not managed correctly. In testing the levels of the active substance in the Lambucid tablet product, it is known that the analysis process produces quite a lot of ethanol waste. This study aims to implement a method of developing the lambucid tablet production analysis test without making ethanol waste. The development method for removing ethanol in the analysis of lambucid tablet samples was carried out by replacing the titration method, which originally required quite a lot of ethanol to become an analytical method based on MA Tentative Promag Fruity Strawbery Tablet with number: MP-I 664253 A, this method has been tested by the team. RnD Andev PT.Kalbe Farma so that the data obtained are valid data with the advantage of not producing ethanol waste in each analysis. Through this method, the company can save Rp. 46.80o.ooo per year for the purchase of pure ethanol.
\end{abstract}

Keywords: zero waste; ethanol; analysis; lambucid tablets

\section{Introduction}

Pharmaceutical Industry is a business entity with permission from the Minister of Health to conduct drug manufacturing activities or restorative materials. Drug manufacture is all stages of producing drugs, including the procurement of initial ingredients and packaging materials, production, packaging, quality control, and quality assurance until obtained medications for distribution. How to Make a Good Medicine, starting now abbreviated as $\mathrm{CPOB}$, is a way of making drugs that aim to ensure that the quality of medicines produced is by the requirements and the purpose of use (BPOM, 2012). Medications are used to improve the quality of human life by curing diseases and prolonging life. However, the increasing use of pharmaceutical products leads to an increase in $\mathrm{B}_{3}$ waste in the wastewater of the pharmaceutical industry (Ananya, 2020).

Drug administration aims to relieve, treat diseases and as a health supplement, but in general, every drug has side effects. It can even be a toxin that can cause the condition to become more severe even in some instances can cause death in consumers. It can happen if the use of the drug is not appropriate for its use or the dose of the active substance consumed is too large than the dose should be, commonly known as "Over Dose" (Jaimini et al., 2013). One of causes of incompatibility of the number of active substances consumed by consumers is due to the fault factor of the manufacturer or 
factory during the production process of the drug. To prevent this from happening, it needs to be a quality assurance of the medicine and the content of active substances in each medicine in production to ensure no mistakes. In medicine, it consists not only of active substances but consists of other components that have a variety of roles such as fillers, binders, destroyers, and so on, all substances are homogenized in one finished product obtained in the form of tablets, caplets, capsules, syrups, injections and others (Zaman et al., 2020).

Tablets are the most widely used pharmaceutical preparations compared to drug preparations in other forms because they are easy and practical in their use (Buwade et al., 2015). Doses are more accurate, can reduce the unpleasantness of the drug ingredients, more stable preparations, and easy production process. Because what will be ascertained or tested is the active substance of the drug, then the test or analysis process can not be done only by physical means, because the physical analysis can not show the content of the active substance of a drug but must be done by an analysis process involving chemical compounds, but almost every research done chemically produces waste both organic and inorganic waste that is $\mathrm{B}_{3}$ waste that has the potential to damage the environment (Silva, 2015). To maintain the quality of the environment to remain stable and not decrease, $\mathrm{B}_{3}$ waste must be processed by its characteristics. The waste to be disposed of to the environment has met the quality standards set by the government. The development of industrio is not in line with the handling of waste because the procurement of waste management and treatment facilities is still considered burdensome for some industries (Syafrudin, 2008).

Efforts have been made to reduce waste in the pharmaceutical industry, including the process of recycling blister packaging consisting of aluminum and plastic coating. The separation of aluminum and polymer coatings from pharmaceutical waste blisters is carried out by exploiting eutectic solvents in a mixture of lactic acid - choline chloride and pure lactic acid that is more environmentally friendly. The fastest separation is obtained when the temperature is raised using lactic acid as a sterile solvent with a content of $90 \%$ weight (Nieminen et al., 2020). The minimization process of captopril from the wastewater of the synthetic pharmaceutical industry is carried out with adsorbents of activated carbon from, but catarinensis $(\mathrm{Bc})$ seeds with a high surface area. Characterization data shows that adsorbents display hydrophilic surfaces due to the presence of multiple polar clusters. The activated carbon material produces TPV $0.392 \mathrm{~cm} 3 \mathrm{~g}-1$ and SBET $1267 \mathrm{~m} 2 \mathrm{~g}-1$. Equilibrium and kinetics data are adapted to Liu's isotherm and Avrami's fractional order. The use of ABc-6oo in the wastewater treatment of the synthetic pharmaceutical industry demonstrates up to $99 \%$ effectiveness in its disposal (Cunha et al., 2020). Absorption of antibiotics (amoxicillin, doxycycline, ciprofloxacin, and sulfadiazine) in wastewater using an ozonization process with an effectiveness of $95 \%$ at an ozone dose $75 \mathrm{mg} / \mathrm{L}$. This study provides a viable method for eliminating harmful substances, contributing to the growing antibiotic resistance problem of pathogenic bacteria (Alsager et al., 2018).

PT. Kalbe Farma Tbk Bekasi, one of the pharmaceutical industries in Indonesia, has an essential role in health. This industry is the manufacturer of various drug preparations, one of which is lambucid tablets as an ulcer medicine. The ethanol waste produced in the production of lambucid tablets is toxic and can pollute the environment if not managed properly. In testing the levels of active substances in Lambucid tablet products, it is known that the analysis process produces a considerable amount of ethanol waste. In the process of determining the level of Aluminum Hydroxide in the sample, there is the potential of organic waste in the form of ethanol and edition which is also dissolved by ethanol, if calculated for one determination of the required level of ethanol as much as $160 \mathrm{ml}$, if assumed every day there are on average 12 samples for analysis then there are 1920 liters of ethanol waste produced per day or 48 liters per month or 576 liters of ethanol waste per year. Therefore, the RnD team is developing to minimize or even eliminate the waste produced. The problem formulation in this study is how to implement the zero-waste method to reduce $B_{3}$ ethanol waste produced. This study aims to implement the process of developing test analysis of lambucid tablet production without making ethanol waste. 


\section{Methods}

\section{1 . Tools and Materials}

The tools used are titration equipment package, Thin Layer Chromatography, and Thin Layer Chromatography Scanner Camag III. While the materials used include Lambucid Tablet (MP-R\&Do0340 Rev.4), Promag Fruity Strawbery Tablet (MP-I 664253 A), HCl (Merck, 99\%), purified water, Na2EDTA solution, $\mathrm{CH}_{3} \mathrm{COONH}_{4}$ buffer, ethanol pro analyst (Merck) solution, auditioned solution, $\mathrm{ZnSO}_{4}$ solution $0.05 \mathrm{~N}$, Orange Xylenol indicator.

\subsection{Flow Chart}

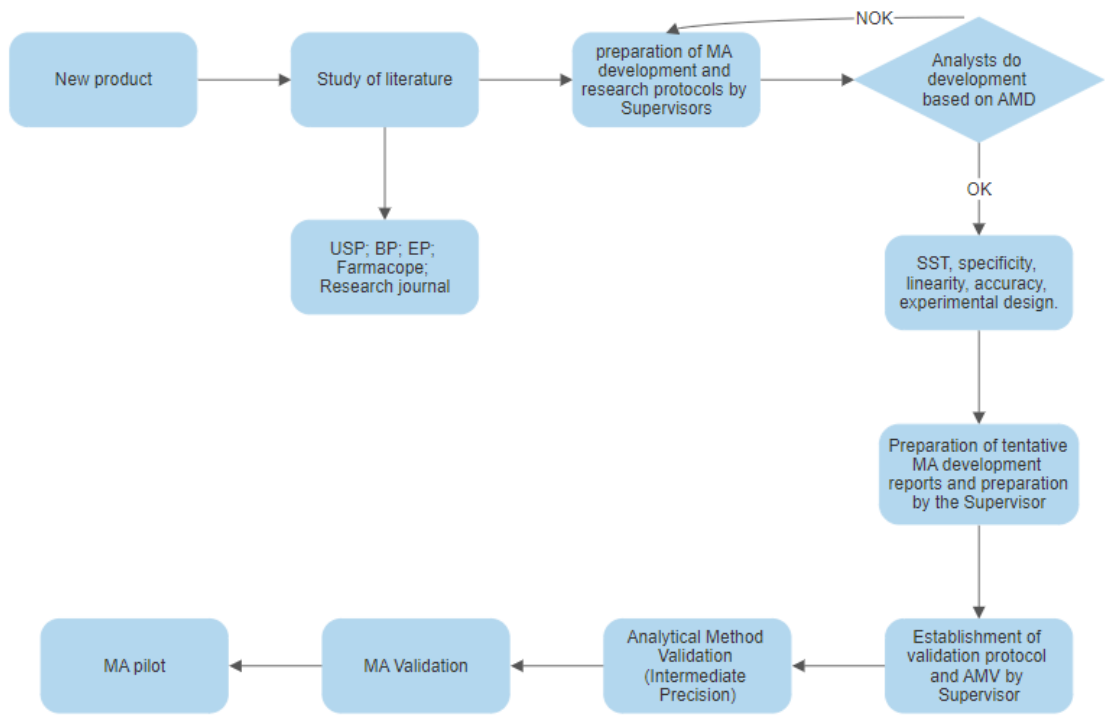

Gambar 1. Development method sample workflow diagram at RnD Andev

\subsection{Research Procedures}

A. Preparation solution manufacturing

A total of 20 lambucid tablets were weighed and calculated on average and then crushed to homogeneous, further weighing samples equivalent to the average weight of one tablet is inserted into the Erlenmeyer $100 \mathrm{~mL}$ adding $5 \mathrm{~mL} \mathrm{HCl}$ p.a and homogenized, then heated on a plate heater until boiling (clear solution) and cooled to room temperature, adding 30 $\mathrm{mL}$ purified water and homogenized then filtered through 2 layers of filter paper into a measuring flask of $100 \mathrm{~mL}$. Furthermore, Erlenmeyer rinsed several times using purified water until clean. The rinsing result is put in the same measuring flask, adding distilled water to the volume limit mark and homogenized (Kalbe RnD, 2020).

B. Determination of the active substance of aluminum hydroxide in lambucid tablets (Initial Method)

Inserted $15.0 \mathrm{~mL}$ of dosage sample solution into Erlenmeyer $250 \mathrm{~mL}$, then added $25.0 \mathrm{~mL}$ Na2EDTA solution and $20 \mathrm{~mL}$ ammonium acetate-acetic acid buffer. Then heated in a hot plate until almost boiling, then chill to room temperature. Then add $50 \mathrm{~mL}$ of p.a ethanol and 2.0 $\mathrm{mL}$ of auditioned and homogenized solution. Mentitrasi with $\mathrm{ZnSO}_{4} 0.05 \mathrm{M}$ until pink sambal recorded $\mathrm{ZnSO}_{4}$ volume needed. Furthermore, six titration data replications are performed for precision data and blank titration. Then calculate the $\mathrm{al}(\mathrm{OH})_{3}$ content in the sample, from this step produced $160 \mathrm{~mL}$ of ethanol waste (Kalbe RnD, 2020).

From the preparation solution carried out the development of analysis by the team to eliminate ethanol (organic substances) in the analysis process based on ma Product Pilot Lambucid Tablet (MPR\&D-oo340 Rev.4) as the initial method and MA Tentative Promag Fruity Strawbery Tablet (MP-I 664253 A) as a method of development, the process can be seen as follows: 
C. Titration measurement procedure of development method

Inserted $15.0 \mathrm{~mL}$ of dosage sample solution into Erlenmeyer $250 \mathrm{~mL}$, then added $015.0 \mathrm{~mL}$ Na2EDTA solution and $20 \mathrm{~mL}$ ammonium acetate-acetic acid buffer. Next, heat in a hot plate until almost boiling. Then titration with $\mathrm{ZnSO}_{4}$ solution $0.05 \mathrm{M}$ (in the hot state) with Xylenol Orange indicator ( \pm four drops) until a change in the colour of red-orange. To record the required $\mathrm{ZnSO}_{4}$ volume, perform up to $6 \mathrm{x}$ replication for precision data. Furthermore, six titration data replications are performed for precision data and blank titration. Then, calculate $\mathrm{Al}(\mathrm{OH})_{3}$ in the sample (Kalbe $\mathrm{RnD}$, 2020).

\section{Result and Discussion}

Waste components resulting from the analysis of active substances are essential factors that need to be considered in the production of drugs in the pharmaceutical industry. The main problem of the process of analysis of active substances is the resulting B3 waste. Therefore, the demands of the analysis process in the pharmaceutical industry today are zero waste or waste minimization analysis process. This can be done by starting to minimize waste at the stage of the production and analysis process. Suitable raw materials in the production process and analysis affect the amount of waste produced (Achillas et al., 2013).

Kalbe contributes to improving the health of Indonesian people, with the availability of complete products ranging from prescription drugs, over-the-counter medicines, consumer health products, and nutritional products. Supported by a spirit of innovation, Kalbe has transformed from humble beginnings to become the most significant public pharmaceutical company in Southeast Asia. Kalbe developed a portfolio of products from the beginning of over-the-counter medicines, developed with prescription drugs and nutritional products until now Kalbe also entered the medical devices segment and health care services, and at the same time-built competence in the field of biotechnology research and development. In line with its mission, Kalbe adheres to the commitment to carry out social responsibility to the community through various social activities focused on four pillars: health, education, environment, and facilities. As a form of environmental concern, Kalbe has also implemented ISO 14001:2004 in production facilities.

Lambucid chewable tablets manufactured by PT. Hexpharm is a subsidiary of PT. Kalbe Farma Tbk has been registered with BPOM. In its development, both in terms of material composition, product packaging, active substances, content analysis methods, and so forth, all carried out laboratium Formulation Packaging Development (PackDev) and Analytical Development (Andev) PT. Kalbe Farma.Tbk. Lambucid is packaged in the form of chewable tablets to facilitate consuming and carrying. Lambucid contains $300 \mathrm{mg}$ Aluminum hydroxide, $300 \mathrm{mg}$ Magnesium hydroxide, and $30 \mathrm{mg}$ simethicone on each chewable tablet. Based on the results of the trial conducted obtained the following data:

$\begin{array}{ll}\text { Product Name / Material } & : \text { Lambucid Tablet } \\ \text { Batch No. } & : \mathrm{IW}_{4} \\ \text { Determination } & : \text { Kadar AL(OH) } \\ \text { Test Method } & :- \text { Initial method titration (with ethanol) } \\ & :- \text { Titration of development methods (without ethanol) }\end{array}$

From the results of titration calculation obtained $\mathrm{Al}(\mathrm{OH})_{3}$ levels in the sample as follows:

Table 1. Levels of aluminum hydroxide in the sample

\begin{tabular}{ccc}
\hline Replication & Initial Method & Development Method \\
\hline Sample 1 & 102.49 & 105.89 \\
Sample 2 & 104.58 & 101.50 \\
Sample 3 & 99.08 & 102.71 \\
\hline
\end{tabular}




\begin{tabular}{ccc}
\hline Replication & Initial Method & Development Method \\
\hline Sample 4 & 103.48 & 102.05 \\
Sample 5 & 104.25 & 105.02 \\
Sample 6 & 103.92 & 102.27 \\
Average & 102.97 & 103.24 \\
\%RSD & 1.98 & 1.73 \\
\hline
\end{tabular}

Source : Primary Data, 2020

Tabel 2. Deviation of aluminum hydroxide levels between the two methods

\begin{tabular}{cc}
\hline Sample & \% Average \\
\hline Initial Method & 102.97 \\
Development Method & 103.24 \\
Average & $\mathbf{1 0 3 . 1 0}$ \\
\%RSD & $\mathbf{0 . 1 9}$ \\
\hline
\end{tabular}

Source : Primary Data, 2020

Tables 1 and 2 above show that the initial method and the development method has a qualified RSD or deviation determined by the company that is $\leq 2 \%$ both from the titration replication performed and the average variation of the rate between the initial method and the development method.

Table 3. Comparison of the benefits obtained from the initial method and the development method

\begin{tabular}{ccc}
\hline Indicator & Initial Method & Development Method \\
\hline $\begin{array}{c}\text { Ethanol Waste Each Sample } \\
\text { Analysis (L) }\end{array}$ & 0.16 & 0.00 \\
$\begin{array}{c}\text { Ethanol waste generated / year } \\
\text { (L) }\end{array}$ & 576 & 0.00 \\
$\begin{array}{c}\text { Ethanol Requirement Once } \\
\text { Sample analysis (L) }\end{array}$ & 0.05 & 0.00 \\
$\begin{array}{c}\text { Ethanol Needs Analysis/ year (L) } \\
\text { Expenditures for purchases of } \\
\text { ethanol / year ( million rupiah ) }\end{array}$ & 180 & 0.00 \\
\hline
\end{tabular}

Based on the above results, the profit obtained can eliminate ethanol waste as much as 576 Liters/year. By converting the initial method to the development method, the company can reduce B3 waste resulting from the production process of ethanol waste to the environment. In this case, the company has successfully conducted the reduction of $\mathrm{B}_{3}$ liquid waste. $\mathrm{B}_{3}$ Waste reduction method has been done by modifying the process by implementing a more efficient production process (PP no 101 the year 2014). In addition to reducing waste, this development method can also save the company's expenditure of Rp 46.80o.0oo- annually to purchase ethanol, assuming the price of ethanol pro analyst Rp 260.000, -/liter.

The target to be eliminated in the work of lambucid tablet samples is organic chemical compounds in the form of ethanol $\left(\mathrm{C}_{2} \mathrm{H}_{5} \mathrm{OH}\right)$ produced during testing of the levels of active substance $\mathrm{Al}(\mathrm{OH})_{3}$ in the sample. Ethanol is one of the organic chemicals that belongs to the $\mathrm{B}_{3}$ waste group because it has flammable properties, irritants and can cause cancer (carcinogenic) (Caetano, 2017). Efforts to eliminate ethanol in the work of lambucid samples on the analysis of the content of active substances of the sample is made by looking for alternative analytical procedures performed by the $\mathrm{RnD}$ team that is expected to be applied to the analysis of lambucid tablet samples based on the theoretical basis that has been validated. Still, in its application, there must be clear proof that the procedure can be applied. After it is proven that the process is valid can only be used to an at sample level test. 
After the test was conducted, it can be known that the new method developed shows good results wherein the procedure ethanol is eliminated in the sample level test process. This is an effort to reduce so that the concept of zero waste can be applied. In the development method carried out by the $\mathrm{RnD}$ team, namely applying the concept of zero waste where $\mathrm{B}_{3}$ waste produced at the time of sample work is minimalist or reduce, the principle of zero waste is a concept of waste management based on recycling activities, reuse, minimization and recycling of waste is a very necessary thing to do to reduce the occurrence of waste that burdens landfills and the environment (Nizar et al., 2017). The principle of ${ }_{3} \mathrm{R}$ (reuse, recycle, reduce) is carried out since the source of waste arises. There is a minimization of waste transported to landfills (Xue et al., 2013, Puspitawati \& Rahdriawan, 2012).

The reduction principle is applied by minimizing ethanol raw materials to reduce waste produced at the end of the production process (Nasir et al., 2015). Zero waste used in this study begins with reducing ethanol solvents as analysis that the waste is also not produced at the end of the reaction at the end of the production process. This concept emphasizes more on efforts to reduce raw materials until, at the end of the process, produced zero ethanol waste is dumped into the environment (Cunha, 2020). Zero waste is applied through the reduce and recycle method with the principle of delaying the buildup of ethanol waste classified as hazardous and toxic waste so that the resulting product does not contain ethanol (Fermin et al., 2020). This shows that all production processes, especially in the analysis process, can be pursued to produce minimal waste. Kalbe continues to make improvements in environmental prevention efforts. Supported by the spirit of innovation, Kalbe will continue to develop itself to increase contributions for all its stakeholders in living and interpret its mission to improve health for a better life.

\section{Conclusions}

The conclusion of this study has been implemented ma tentative method Promag Fruity Strawbery Tablet with the number: MP-I 664253 A on testing the level of active substances in lambucid tablet products instead of titration method that initially needed ethanol which is quite a lot of development methods that do not require ethanol, so it does not produce B3 ethanol waste. This method has been through a validation test by the Andev PT $\mathrm{RnD}$ team. Kalbe Farma so that the data obtained is valid data with the advantage of not producing ethanol waste in every analysis. Through this method, the company can make savings of Rp 46.80o.ooo annually to purchase pure ethanol. Further research can be developed by manually replacing titration methods with titrations that take advantage of technological advances by using auto titrators (titrations with instrumental methods) to eliminate reagents involved in manual titration processes such as $\mathrm{pH}$ buffers and titration indicators. Variations in volume, sample concentration, and reagents can also be developed. The number of samples and reagents used can also be optimized to reduce the resulting B3 waste.

\section{Acknowledgement}

Researchers thanked the Research and Development Team of PT Kalbe Farma Tbk, who has helped implement this development method, and Pelita Bangsa University to support research funds to be carried out correctly.

\section{References}

Achillas, C., Moussiopoulos, N., Karagiannidis, A., Banias, G., \& Perkoulidis, G. 2013. The use of multicriteria decision analysis to tackle waste management problems: A literature review. Waste Management \& Research. 31 (2): 115-129.

Alsager, O. A., Alnajrani, M. N., Abuelizz, H. A., \& Aldaghmani, I. A. 2018. Removal of antibiotics from water and waste milk by ozonation: kinetics, by products, and antimicrobial activity. Ecotoxicology and Environmental Safety,158, 114-122. 
Ananya Shah, A., \& Shah, M., 2020. Characterisation and bioremediation of wastewater: A review exploring bioremediation as a sustainable technique for pharmaceutical wastewater, Groundwater for Sustainable Development 11 (2020) 100383.

Buwade, P., Shailendra Jadiya., Tripti Shukla., \& Neeraj Upmanyu. 2015. Advantages Of Immediate Release Tablets Over The Other Tablet Forms. World Journal of Pharmaceutical Research; 2015. 4(11): pp.757-78o

Badan Pengawas Obat dan Makanan. 2012. Pedoman Cara Pembuatan Obat yang Baik (CPOB). Jakarta: Badan Pengawas Obat dan Makanan.

Caetano, N. S., Caldeira, D., Martins, A. A., \& Mata, T. M. 2017. Valorisation of Spent Coffee Grounds: Production of Biodiesel via Enzymatic Catalysis with Ethanol and a Co-solvent. Waste and Biomass Valorization, 8(6), 1981-1994.

Cunha, M. R., Lima, E. C., Lima, D. R., da Silva R. S., Thue, P. S., Seliem, M. K., \& H Larsson, S. 2020. Removal of captopril pharmaceutical from synthetic pharmaceutical industry wastewaters: use of activated carbon derived from Butia catarinensis. Journal of Environmental Chemical Engineering, 104506.

Fermin, U., Purwanti, R.E., Kilowasid, L.M.H., Nuraida, W., Handayani, F.D., \& Mudi, L. 2020. Penerapan Zero Wastedi Pemukiman Warga Sekitar Tempat Pembuangan Akhir Sampah di Kecamatan Puuwatu Kendari. Agrokreatif Mare t2020, Vol 6(1): 1-7.

Jaimini, Manish \& Saurabh Rawat. 2013. A Review on Immediate Release Drug Delivery System. Research Journal of Pharmaceutical, Biological and Chemical Sciences, 4(2): pp.1-10

Kalbe RnD. 2020. MA Produk Pilot Lambucid Tablet (MP-R\&D-oo34o Rev.4)

Nasir, M., Saputro, E.P., Handayani, S. 2015. Manajemen Pengelolaan Limbah Industri. Benefit Jurnal Manajemen dan Bisnis. Volume 19 (2). pp: 143-149

Nieminen, J., Anugwom, I., Kallioinen, M., \& Mänttäri, M. 2020. Green solvents in recovery of aluminium and plastic from waste pharmaceutical blister packaging. Waste Management, 107, 20-27.

Nizar, M., Munir, E., Munawar, E. and Irvan, I., 2017. Manajemen Pengelolaan Sampah Kota Berdasarkan Konsep Zero Waste: Studi Literatur. Jurnal Serambi Engineering, 1(2).

Pemerintah Republik Indonesia. 2014. Peraturan Pemerintah Nomor 101 Tahun 2014 tentang pengelolaan limbah berbahaya dan beracun (B3). Jakarta: Anonim.

Puspitawati, Y. \& Rahdriawan, M., 2012. Kajian pengelolaan sampah berbasis masyarakat dengan konsep 3R (reduce, reuse, recycle) di Kelurahan Larangan Kota Cirebon. Jurnal Pembangunan Wilayah \& Kota, 8(4), pp.349-359.

Syafrudin. 2008. Evaluasi Sistem Pengelolaan Limbah Padat B3 PT. Indofarma, Tbk Bekasi. TEKNIK Vol. 29 No. 3. pp: 214-219

Silva, B., Costa, F., Neves, \& I.C., Tavares, T. 2015. Psychiatric Pharmaceuticals as Emerging Contaminants in Wastewater. Springer, Heidelberg, pp. 96.

Xue, M., Li, J., \& Xu, Z. 2013. Management strategies on the industrialization road of state of the art technologies for e-waste recycling: the case study of electrostatic separation: A review. Waste Management \& Research. 31 (2): 130-140.

Zaman, Nadya Nurul \& Sopyan, Iyan. 2020. Metode Pembuatan dan kerusakan Sediaan Tablet. Majalah Farmasetika, 5(2) 2020, 82-93. 